\title{
Evaluation of Extracurricular Sports Activities as an Educational Element for Sustainable Development in Educational Institutions
}

\author{
Raquel Pérez-Ordás ${ }^{1, * \mathbb{C}}$, Mónica Aznar Cebamanos ${ }^{2}$, Román Nuviala ${ }^{3}$ and Alberto Nuviala ${ }^{4}$ \\ 1 Faculty of Physical Activity Sciences and Sport, Universidad Pablo de Olavide, 41013 Seville, Spain \\ 2 Departamento de Expresion Musical, Plastica y Corporal, Universidad de Zaragoza, 50009 Zaragoza, Spain; \\ moaznar@unizar.es \\ 3 Faculty of Education Sciences, Universidad de Cádiz, 11001 Cádiz, Spain; roman.nuviala@uca.es \\ 4 Department of Sports and Computer Sciences, Universidad Pablo de Olavide, 41013 Seville, Spain; \\ anuvnuv@upo.es \\ * Correspondence: rperord@upo.es; Tel.: +34-637-537-469
}

Received: 13 May 2019; Accepted: 17 June 2019; Published: 25 June 2019

\begin{abstract}
Education that instills healthy habits has acquired much attention in recent years due to concerns related to obesity and the sedentary lifestyle of the scholastic population. Extracurricular sports activities can contribute to the creation of healthy habits and can promote active lifestyles. These positive habits provide social benefits and are a facilitator of sustainable development. Thisstudy had two objectives: To assess the quality and value of extracurricular sports activities offered by schools, as well as the satisfaction of the participants and their future intentions to participate; and to assess the relationship between these constructs, with the aim of identifying factors that encourage schoolchildren to be active. Information was gathered from 1080 children in secondary education in Spain $(n=1080)$ (65.90\% boys, $13.76 \pm 1.39$ years). The instruments used were the Scale of Perception of Sports Organizations (EPOD2) and a future intentions scale. The evaluation of satisfaction, quality, and value, as well as the intentions expressed by the young athletes to continue participating in extracurricular sports activities were positive, with average values close to the maximum. The best-rated quality variables were human resources. A significant association was identified between communication and loyalty, and response capacity and sports spaces. Likewise, perceived satisfaction and value were related to loyalty and price. In short, student perceptions establish a clear relationship between evaluations of activities and the intention to continue practicing sports in schools.
\end{abstract}

Keywords: physical activity; service quality; satisfaction; sustainability; active lifestyle; loyalty

\section{Introduction}

Physical activity and sport in childhood and adolescence seems to be an important tool to promote the sustainable development of societies and plays an essential role in strengthening each of the eight Millennium Development Goals (MDGs). This has been recognized in numerous resolutions made by the UN General Assembly; for example, resolution 70/1, adopted in 2015, entitled "Transforming our world: the 2030 Agenda for Sustainable Development", recognizes the role of sport in the promotion of social progress [1]. Adolescence is the ideal stage to consolidate an education that integrates the principles and values of sustainability [2].Physical activities and sports, apart from being a fundamental instrument in the promotion of a nonsedentary lifestyle, combined with the curriculum are necessary for a complete and sustainable education, aimed at achieving the various objectives of the MDGs. When participating in sports and physical school activities, students are exposed to fundamental sports values including teamwork, fair play, respect for rules and others, and cooperation; all values and 
skills that are essential in an individual's personal, professional, and social life within communities and societies. Encouraging access to and participation in the practice of physical activity is a strategy that enables inclusive and equitable quality education and promotes learning opportunities for all, as defined by the fourth objective of the MDGs [1].

It is also the ideal time for the adoption of physical activity behaviors [3-5]. However, encouraging adolescents to acquire an active and healthy lifestyle is a challenge [6-9]. Schools are the ideal setting for fostering active behaviors at this stage, because they enable millions of individuals within this age range to play sports [10-12]. Initiatives that foster physical activity during school hours, such as an active means of commuting to school or physical activity programs within the educational institutions [13,14], have a significant effect on social and environmental sustainability. They also encourage equal participation, working to achieve gender equality and the empowerment of all women and girls, as is established in the fifth MDGs objective, whilst also having a positive effect on the health and psychosocial state [1,15-19].

Adolescence is a critical time for the development of healthy lifestyle habits, which tend to last throughout adulthood [20]. A harmful habit that affects adolescents and adults is physical inactivity. Currently, $81 \%$ of school-age adolescents worldwide are not active enough [21-23].

Extracurricular sports activity programs offered by schools have proven to be efficient tools for reducing physical inactivity among adolescents [24]. However, according to the Spanish National Sports Council (Consejo Superior de Deporte, CSD), the number of participants in these activities is lower than desired and there is a high dropout rate from these programs [25]. An educational intervention from the school center can provide a novel approach to encouraging schoolchildren to engage in physical activity, thus enabling the acquisition of healthy habits aimed at guaranteeing a healthy life and promoting the wellbeing of everyone at all ages, as defined by MDG number three [1,26].

Identifying the factors that encourage an active lifestyle is crucial for future educational programs. These programs can provide people with the abilities, skills, and healthy lifestyle habits necessary to achieve global sustainable development, providing a balance between economic, social, and environmental sustainability [2-6].

The Aichi-Nagoya Declaration recognizes that people are at the center of sustainable development [27], defined as "development that meets the needs of the present without compromising the ability of future generations to meet their own needs" [26]. Therefore, promoting active lifestyles in education and increasing loyalty among adolescents towards sports practices are two lines of inquiry that are relevant to educational programs within the field ofsocial sustainability.

Creating loyalty is crucial in the acquisition of healthy lifestyle habits and cannot be simply understood as repetitive practices [28]. Loyalty includes cognitive aspects (such as improvement in the execution and knowledge of habits), attitude aspects (such as recommending a service or word-of-mouth dissemination), and behavioral aspects (the enjoyment of the activity or the social relationships that are established) $[28,29]$.

Loyalty is a concept that is included within a set of user intentions that later turn into behaviors. Specifically, among the future intentions of individuals who use sports services are loyalty to the organization that organizes the leisure or physical sports activities, the ability to adapt to an increase in the price of the service, and the willingness to submit complaints and claims as a tool for repairing nonconformities for the service received [30]. Apart from the health benefits, creating loyalty among schoolchildren towards extracurricular sports activities offered by educational institutions leads to economic benefits and so investment in educational improvements [31], an increase in the number of young athletes due to word-of-mouth recommendations from classmates [32], and simultaneous participation in other sports activities [33].

Satisfaction and adherence to physical activity also entail social aspects relating to reduced health expenses [34], better quality of life [35,36], higher life expectancy [37], active ageing [38-40], and indices that have a global impact on sustainability and that are beneficial to the development of the community, 
thus making for a society that is capable of managing its health and able to select lifestyle habits that provide longer-lasting and independent health [41-43].

Previous studies have proved the importance of perceived quality, perceived value, and satisfaction as predictors of loyalty among users of sports services [44-46]. Both in sports centers with physical activities aimed at adults [47] and in activities or sports services aimed at children and adolescents, sports systems with lower perceptions of quality have higher dropout rates, with the choice of sports activities and human resources being the factors with the highest negative association with dropout rates [48]. To our knowledge, no previous studies have evaluated quality, value, and satisfaction in extracurricular sports activities offered by educational institutions or assessed whether these variables are associated with loyalty or future intentions to continue in educational sports services offered by the schools.

This research adopted a model that relates the perceived quality, the dimensions that integrate it, the perceived value, and satisfaction of participation in sports with the behavioral intentions of school-age users of sports services [48]. The model also explored the correlations between the constructs present in the model (the sports instructor, sports facilities, equipment, sports activity, communication, service personnel, perceived value, and satisfaction) and the dimensions of loyalty, response to price, and response capacity (Figure 1). Previous studies have examined models that relate perceived quality - understood as a single dimension - with the value, satisfaction, and future intentions of users-understood as a single dimension - in adult populations [44-46,49]. The model in this study focused on school-age boys and girls to determine the influence of each of the dimensions of perceived quality, perceived value, and satisfaction on their future intentions to participate in sports. Previously used research models have not provided information on the impact of the different dimensions of quality on the future behaviors of sports participation of adolescents or the impact on the schools themselves.

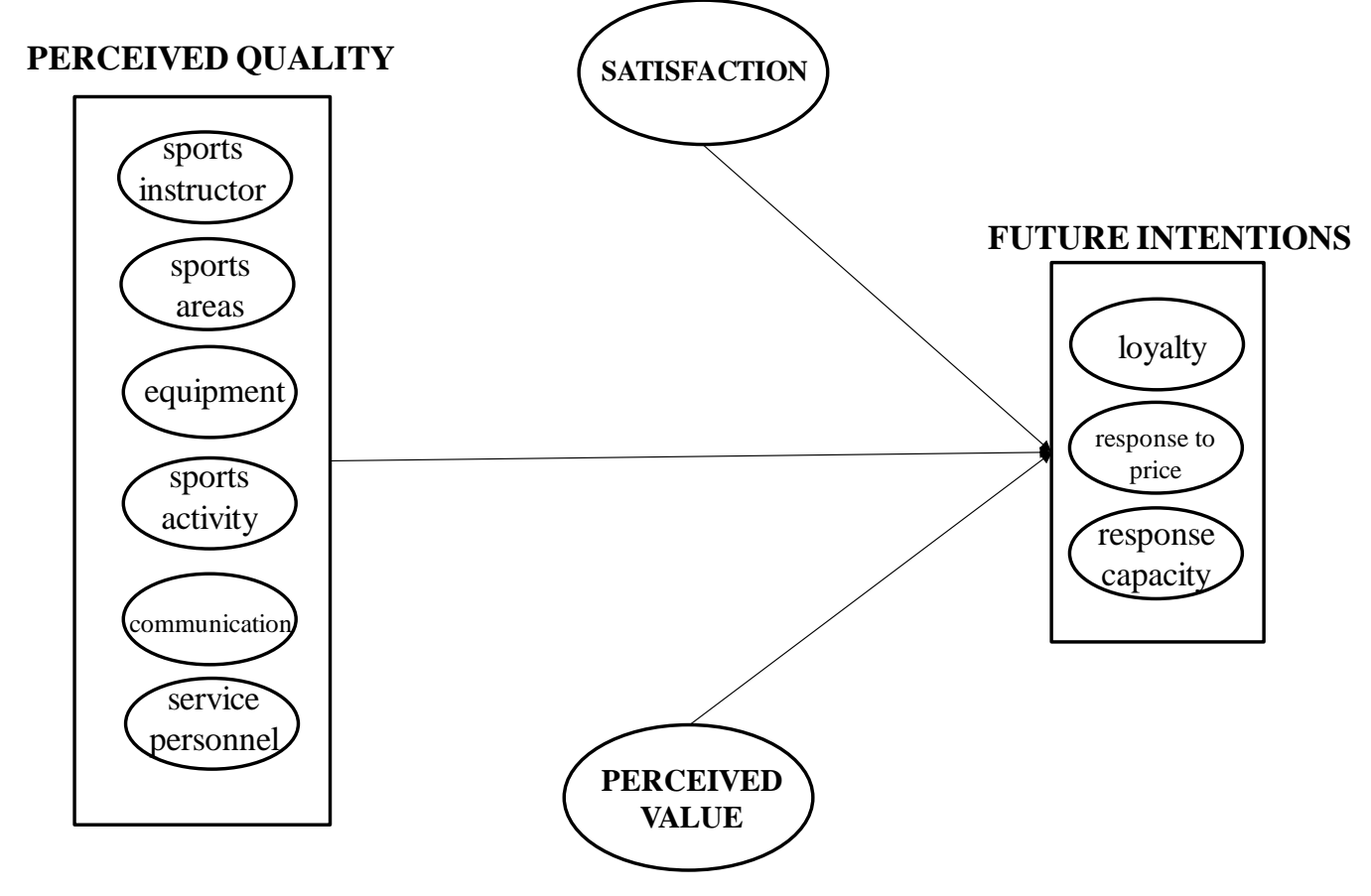

Figure 1. The relationship between the dimensions of quality, satisfaction, and perceived value with the dimension of future intentions of users of sports services.

On the basis of the extant literature, the following hypotheses were examined:

Hypothesis H1. Loyalty has as a precursor the evaluation of the sports instructor (H 1.1.), sports areas (H 1.2.), equipment (H 1.3.), sports activity (H 1.4.), communication (H 1.5.), and service personnel (H 1.6.) [44-46,48]. 
Hypothesis H2. The response to price has as a precursor the evaluation of the sports instructor (H 2.1.), sports areas (H 2.2.), equipment (H 2.3.), sports activity (H 2.4.), communication (H 2.5.), and service personnel (H 2.6.) [44-46,48].

Hypothesis H3. The response capacity has as a precursor the evaluation of the sports instructor (H 3.1.), sports areas (H 3.2.), equipment (H 3.3.), sports activity (H 3.4.), communication (H 3.5.), and service personnel (H 2.6.) [44-46,48].

Hypothesis H4. The perceived value has an influence on loyalty (H 4.1.), the response to price (H 4.2.), and the response capacity (H 4.3.) [44-46,48].

Hypothesis H5. Satisfaction has an influence on loyalty (H 5.1.), the response to price (H 5.2.), and the response capacity (H 5.3.) [44-46,48].

\section{Materials and Methods}

\subsection{Participants}

The study sample consisted of 1080 students in secondary education who voluntarily agreed to take part in the study and who were participants in extracurricular sports activities in 22 educational centers in a Spanish city. The age of the participants was between 11 and 16 years, with an average age of $13.76 \pm 1.39$ years. Boys made up $65 \%$ of the sample, while girls accounted for $35 \%$ of the sample.

\subsection{Instruments}

To measure quality, value, and satisfaction, the Scale of Perception of Sports Organizations (EPOD2) questionnaire was used [50]. This instrument measures perceived quality (20 items of which 4 are concerned with the sports instructor, 3 the sports areas, 3 the equipment, 5 the sports activity, 3 communication, and 2 the service personnel); perceived value ( 1 item); and satisfaction (4 items). These are Likert-type scales from 1 to 5 . After the completion of the fieldwork, the reliability, measured with Cronbach's alpha, was 0.906 for the scale that measures perceived quality and 0.891 for the scale that measures satisfaction.

To measure future intentions, the scale translated and adapted to sports services by Nuviala et al. [50] was used. The scale is made up of 10 items divided into 3 dimensions: loyalty ( 5 items), response to price ( 2 items), and response capacity ( 3 items). This is a Likert-type scale from 1 to 7 . After the completion of the fieldwork, the reliability, measured with Cronbach's alpha, was 0.812 . Several sociodemographic questions were added with the aim of finding out more about the organization that sponsors the physical activity.

\subsection{Procedure}

Before conducting the study, authorization was requested from the different sports organizations. As the study involved minors, the parents of the students were informed of the nature of the work, authorization was requested, and consent was obtained. The information was processed in compliance with Spanish data protection law Organic Law 15/1999 of 13December. Likewise, the principles established in the Declaration of Helsinki [51] were respected. The questionnaire mode was self-administered in the presence of an interviewer, and the responses were provided. The time spent completing the survey was $10 \mathrm{~min}$.

\subsection{Statistical Analysis}

A descriptive analysis was performed by calculating the mean and standard deviation with SPSS v.2.1 software. Confirmatory factor analysis was then performed with AMOS v.2.1 software. 
The following indicators were used to evaluate goodness: the ratio between $\chi 2$ and the number of degrees of freedom ( $\chi 2 / \mathrm{df})$; absolute fit indices: Goodness of Fit Index (GFI), Root Mean Residual (RMR), and the Root Mean Square Error of Approximation (RMSEA); and incremental fit index: Index de Tucker-Lewis (TLI), Comparative Fit Index (CFI), and Normed Fit Index (IFI). Finally, the regression coefficients (standardized and nonstandardized) were calculated for the relationships in the model.

\section{Results}

The results illustrate a good evaluation of the extracurricular sports activities offered by the educational institution. The obtained evaluation for satisfaction was higher than that for quality. Human resources obtained the best evaluation among the dimensions included in quality, while areas for practicing physical activities received the lowest evaluation.

The future intentions of the students in relation to the extracurricular sports activities offered by the educational institution were good. Loyalty to the organization obtained the best evaluation, while response capacity received the worst evaluation within the dimensions of future intentions (Table 1).

The results of Table 1 show that the perceived quality, value, satisfaction, and future intentions constructs correlate positively with each other. Only the dimension of response (future intentions) does not correlate with value, satisfaction, and some of the perceived quality dimensions. The results suggest that an increase in the perceived quality implies an improvement in the future intentions of continuing to perform extracurricular sports activities in the educational centers by the students. In the same way, an increase in value and satisfaction translates into an increase in future intentions, with the exception of the size-response capacity.

The fit indices of the analyzed model provided correct values, with the result of the ratio between $\chi 2$ and the number of degrees of freedom ( $\chi 2 / \mathrm{df})$ being 1856 . The absolute fit indices produced correct values (GFI: 0.913; RMR: 0.093; RMSEA: 0.038). Likewise, the incremental fit indices were acceptable (TLI: 0.946; CFI: 0.954; IFI: 0.954).

Table 2 shows how the dimension of perceived quality-communication was positively associated with loyalty $(\beta=0.225, p=0.015)$, which confirms the hypothesis $\mathrm{H} 1.5$. The dimension of spaces was negatively associated with the response capacity $(\beta=-0.154, p=0.049)$. Perceived value and satisfaction also produced a positive association with the dimensions of future intentions-loyalty $(\beta=0.221, p \leq 0.001 ; \beta=0.391, p \leq 0.001)(\mathrm{H} 4.1 . ; \mathrm{H}$ 5.1.) and price $(\beta=0.109, p=0.037 ; \beta=0.258$, $p \leq 0.001)(\mathrm{H}$ 4.2.; H 5.2.). The rest of the dimensions were not associated with each other. 
Table 1. Descriptive, internal consistency (diagonal), and intercorrelations for study variables among extracurricular sports activities $(\mathrm{N}=1080)$.

\begin{tabular}{|c|c|c|c|c|c|c|c|c|c|c|c|c|c|c|c|}
\hline $\begin{array}{c}\text { Construct and } \\
\text { Dimensions }\end{array}$ & $\mathbf{M}$ & SD & 1 & 2 & 3 & 4 & 5 & 6 & 7 & 8 & 9 & 10 & 11 & 12 & 13 \\
\hline 1. Perceived quality & 3.79 & 0.66 & 0.906 & $0.674^{* *}$ & $0.685^{* *}$ & $0.731^{* *}$ & $0.815^{* *}$ & $0.743^{* *}$ & $0.701^{* *}$ & $0.534^{* *}$ & $0.502 * *$ & $0.496^{* *}$ & $0.577^{* *}$ & $0.357^{* *}$ & $0.063 *$ \\
\hline 2. Sports instructors & 4.07 & 0.90 & & 0.874 & $0.194 * *$ & $0.264^{* *}$ & $0.606^{* *}$ & $0.331 * *$ & $0.377^{* *}$ & $0.394 * *$ & $0.292 * *$ & $0.317^{* *}$ & $0.385^{* *}$ & $0.205^{* *}$ & 0.043 \\
\hline 3. Spaces & 3.33 & 1.11 & & & 0.840 & $0.540^{* *}$ & $0.378^{* *}$ & $0.444^{* *}$ & $0.462 * *$ & $0.261^{* *}$ & $0.299 * *$ & $0.238^{* *}$ & $0.315^{* *}$ & $0.181 * *$ & -0.014 \\
\hline 4. Equipment & 3.62 & 1.02 & & & & 0.842 & $0.444^{* *}$ & $0.501^{* *}$ & $0.448^{* *}$ & $0.335^{* *}$ & $0.345^{* *}$ & $0.330 * *$ & $0.387^{* *}$ & $0.275^{* *}$ & 0.021 \\
\hline 5. Activity & 3.98 & 0.70 & & & & & 0.762 & $0.522 * *$ & $0.476^{* *}$ & $0.548^{* *}$ & $0.402 * *$ & $0.453^{* *}$ & $0.508^{* *}$ & $0.294^{* *}$ & $0.099 * *$ \\
\hline 6. Communication & 3.55 & 0.93 & & & & & & 0.750 & $0.541 * *$ & $0.362 * *$ & $0.434^{* *}$ & $0.435^{* *}$ & $0.461^{* *}$ & $0.304^{* *}$ & $0.119 * *$ \\
\hline 7. Service personnel & 4.00 & 0.93 & & & & & & & 0.815 & $0.465^{* *}$ & $0.470 * *$ & $0.397^{* *}$ & $0.453^{* *}$ & $0.251^{* *}$ & $0.069 *$ \\
\hline 8. Satisfaction & 4.33 & 0.77 & & & & & & & & 0.891 & $0.373 * *$ & $0.447^{* *}$ & $0.564^{* *}$ & $0.268^{* *}$ & 0.037 \\
\hline 9. Value & 3.72 & 1.06 & & & & & & & & & - & $0.414^{* *}$ & $0.500 * *$ & $0.268^{* *}$ & 0.050 \\
\hline 10 Future intentions & 4.74 & 0.92 & & & & & & & & & & 0.812 & $0.818^{* *}$ & $0.729^{* *}$ & $0.619^{* *}$ \\
\hline 11. Loyalty & 5.20 & 1.16 & & & & & & & & & & & 0.809 & $0.495^{* *}$ & $0.118^{* *}$ \\
\hline 12.Price & 4.48 & 1.41 & & & & & & & & & & & & 0.534 & $0.278^{* *}$ \\
\hline 13. Response capacity & 4.16 & 1.45 & & & & & & & & & & & & & 0.701 \\
\hline
\end{tabular}


Table 2. Standardized and unstandardized regression coefficients for the model relating to perceived quality, perceived value, satisfaction, and future intentions: hypothesis verification.

\begin{tabular}{lcccccc}
\hline & Hypothesis & & Estimates & Beta & $p$ & Verification \\
\hline H 1.1. & Loyalty & Instructors & 0.130 & 0.097 & 0.211 & Not established \\
H 1.2. & Loyalty & Spaces & 0.015 & 0.014 & 0.799 & Not established \\
H 1.3. & Loyalty & Equipment & 0.109 & 0.087 & 0.113 & Not established \\
H 1.4. & Loyalty & Activity & 0.016 & 0.009 & 0.943 & Not established \\
H 1.5. & Loyalty & Communication & 0.318 & 0.225 & 0.015 & Established \\
H.1.6. & Loyalty & Service personnel & -0.025 & -0.017 & 0.824 & Not established \\
H 2.1. & Price & Instructors & 0.129 & 0.081 & 0.429 & Not established \\
H 2.2. & Price & Spaces & -0.054 & -0.042 & 0.562 & Not established \\
H 2.3. & Price & Equipment & 0.196 & 0.133 & 0.066 & Not established \\
H 2.4. & Price & Activity & -0.024 & -0.011 & 0.946 & Not established \\
H 2.5. & Price & Communication & 0.378 & 0.227 & 0.074 & Not established \\
H.2.6. & Price & Service personnel & -0.110 & -0.061 & 0.542 & Not established \\
H 3.1. & Response & Instructors & -0.079 & -0.077 & 0.452 & Not established \\
H 3.2. & Response & Spaces & -0.128 & -0.154 & 0.049 & Established \\
H 3.3. & Response & Equipment & -0.057 & -0.060 & 0.438 & Not established \\
H 3.4. & Response & Activity & 0.207 & 0.152 & 0.340 & Not established \\
H 3.5. & Response & Communication & 0.247 & 0.230 & 0.058 & Not established \\
H.3.6. & Response & Service personnel & -0.024 & -0.021 & 0.835 & Not established \\
H 4.1. & Loyalty & Value & 0.241 & 0.221 & $\geq 0.001$ & Established \\
H 4.2. & Price & Value & 0.141 & 0.109 & 0.037 & Established \\
H 4.3. & Response & Value & -0.024 & -0.029 & 0.612 & Not established \\
H 5.1. & Loyalty & Satisfaction & 0.563 & 0.391 & $\geq 0.001$ & Established \\
H 5.2. & Price & Satisfaction & 0.438 & 0.258 & $\geq 0.001$ & Established \\
H 5.3. & Response & Satisfaction & -0.025 & -0.023 & 0.765 & Not established \\
\hline & & Source: compiled & & &
\end{tabular}

Source: compiled by authors.

\section{Discussion}

This study measures quality, value, satisfaction, and future intentions of schoolchildren with respect to extracurricular sports activities offered by educational institutions, which according to the UN General Assembly is an important tool to promote the sustainable development of societies. It also investigates whether the dimensions concerning the evaluation of the extracurricular sports service are associated with the intention to continue with these activities. The results reveal a good evaluation of extracurricular sports activities in the four constructs studied. A relationship exists between some of the variables studied and the future intentions of the students with respect to the educational sports services received, making these results relevant in relation to the sustainability objectives that United Nations Educational, Scientific and Cultural Organization (UNESCO) provides for 2030.

The evaluation of perceived quality, perceived value, and satisfaction regarding the physical activities offered by the educational institutions were positive. The results were similar to those obtained by Bernal [52] regarding quality ( $3.82 \pm 0.50)$, value (4.00 \pm 0.95$)$, and satisfaction (4.20 \pm 0.72$)$ with a sample of 2118 athletes of all ages and those obtained by Nuviala et al. [48] regarding quality $(3.80 \pm 0.61)$, value $(3.89 \pm 0.94)$, and satisfaction $(4.14 \pm 0.7)$ with a sample of 646 users of a public sports service. The dimension of sports instructors, which was included in perceived quality, obtained the highest score from the students in accordance with other surveys and other group types [52-54]. It is important to highlight the influence that sports instructors have on satisfaction as an antecedent of loyalty to sports services [44-46,55]. This translates into a very important strategy to be developed, in order to ensure that the students continue doing sports activities in pursuit of the achievement of UNESCO's objectives.

The results of perceived quality in this study are compared with those obtained in the study conducted with schoolchildren who practice sports activities in rural areas conducted by Nuviala et al. [56]. We are not aware of any studies published regarding satisfaction and perceived 
value among schoolchildren. The evaluation of perceived quality obtained was very similar in the two surveys. Sports instructors obtained the best evaluation, and sports spaces the worst. The result for sports instructors illustrates a good perception among schoolchildren, an outcome that is extremely relevant with regard to the individuals continuing with the sport [56]. It is important to mention that this opinion among adolescents influences the opinion of their parents regarding the sports instructors. Parents encourage sports activities if they perceive a pleasant and educational environment in which the instructors are considered to be responsible, punctual, supportive, and inclined to use games, and in which winning is not the priority $[57,58]$.

Sports spaces were the most poorly evaluated, as in the survey by Nuviala et al. [56] conducted with Spanish schoolchildren (both boys and girls) who took part in sports activities during their free time. This result coincides with that obtained in studies that considered the facilities in the sports centers to be deficient as a result of focusing more on economic aspects than on safety and functionality aspects [59,60]. This limitation in school services is damaging to the image of the school, as expectations are not being met.

Satisfaction with the extracurricular sports activities offered by the educational institutions was the most highly rated construct, in line with the results in other studies $[48,52]$. This may be due to the specific characteristics of quality as an opinion that lasts over the course of time, while satisfaction is a temporary opinion referring to a specific service [61,62]. This indicates that satisfaction to a large extent depends on emotional aspects [63] and a postconsumption and/or post-use evaluation that could change in each transaction and that is the result of psychosocial cognitive and affective processes. This is an aspect that cannot be escaped by those responsible for the extracurricular sports activities offered by the educational institutions, and they should try to relate physical activity with the development and improvement of affective and cognitive processes among adolescents.

The future intentions of the young athletes obtained evaluations of $4.7 \pm 0.92$, out of 7 , with the loyalty dimension obtaining the best score. These results are similar to those obtained by Bernal [52] for an adult population $(4.54 \pm 0.87)$ in sports services, and in general indicate a willingness to continue with physical education activities in the educational institutions. The 2030 Agenda calls on States to collaborate with communities, civil society, international organizations, and the business sector in the promotion of sports activities and ventures due to the outstanding role of sport in achieving the Sustainable Development Goals (SDGs). A positive association has been established between some of the dimensions of quality, value, and satisfaction with the future intentions of the students who participated in extracurricular physical activities in the educational center. Similar results have been found in studies of adults who used sports services [44,64,65], in which the tested models related perceived quality, perceived value, satisfaction, and fidelity. Likewise, studies of spectators who attended sporting events $[31,66]$ established a positive relationship between the loyalty of these fans and the evaluations related to the sports spectacle. However, there appear to be no studies on record that have tried to relate the quality, value, and satisfaction variables with the future intentions of school populations that perform extracurricular physical activities in educational centers. On the basis of our results, it is important to continue focusing on quality, the dimensions that integrate it, and value and satisfaction as loyalty strategies for these types of educational sports services.

Analyzing the relationships between the constructs, we observed that there is an association between some of the dimensions of quality and future intentions. The communication dimension was related to loyalty (H 1.5.), while spaces were related to the response capacity (H 3.2.).

Our results cannot be corroborated by those of other works on sports services, because such services are different from those offered by educational centers for schoolchildren, although all of them reflect the existence of a direct relationship between quality perceived by the client and fidelity $[31,66]$. It is noteworthy that the spaces dimension was the only one related to the response capacity. Theodorakis et al. [46] similarly worked on the connection between perceived quality, place attachment, and customer loyalty in the context of recreational skiing in northern Greece. In that study, the authors concluded that attachment to the place has a mediating effect on the relationship 
between quality of service and customer loyalty. It can therefore be assumed that the evaluation of sports venues affects the attachment to extracurricular sports services. Greater loyalty to the service is related to a greater response capacity [48]. This means that a greater possibility of presenting claims, complaints, and suggestions can satisfy the demands of users and thereby increase their loyalty.

Howat and Assaker [43] found that satisfaction had a significant and positive effect on future intentions. Using the same research instruments, Bernal [52] found that the loyalty and price dimensions have satisfaction as a precedent, a result that is repeated for the population of our study (H 5.1., $\mathrm{H}$ 5.2.). Since satisfaction is one of the most significant constructs that determines the loyalty of service users [67-69], it is important that these services achieve the full satisfaction of schoolchildren.

The perceived value is significantly related to two dimensions of future intentions: loyalty and price (H 4.1., $\mathrm{H}$ 4.2.). These results coincide with similar works that have established relationships between value and sports loyalty [6]. Authors such as McDougall and Levesque [70] not only recognized this relationship, but also proposed that perceived value, along with satisfaction, are the most important factors influencing the future intentions and behaviors of users. In their study, the beta values of the perceived value were lower than the satisfaction values. However, the subjects of this research were minors, and the perceived value could be related to age [53].

The results of our study show that two measures are necessary to increase the fidelity of young people to the extracurricular physical activities offered by educational centers. These measures are improving and achieving good and fluid communication with the athlete and improving the practice spaces of the extracurricular activities offered in the educational centers. An improvement in quality in these areas will increase the loyalty of athletes.

When examining strategies to increase loyalty, it is also necessary to consider the perception of value and the satisfaction of the athlete. Establishing strategies for the price of activities and implementing strategies by gender are essential in the management of extracurricular activities $[48,53]$ and can improve the loyalty of current users. In the long run, this will generate various social and economic benefits for health and have an impact on social sustainability, since sports and their regular practice contribute to achieving the United Nations Sustainable Development Goals. In terms of satisfaction regarding activities and sports instructors, the literature [47-50] suggests that a wide range of activities and receptive, pleasant, and well-trained staff are important for young people. Sports instructors are one of the best-valued elements with respect to perceived quality, although the results do not show a significant relationship with loyalty. Nonetheless, these factors are essential in the assessment of the satisfaction of school-age athletes $[48,53,56]$. This means that it is necessary for sports instructors to receive excellent pedagogical and technical trainingto achieve the objectives of sustainable social development.

\section{Conclusions}

Sport and physical activity are important tools for achieving the sustainable development goals of the United Nations [1]. According to these goals, not only educational and sports institutions, but also the business sector are encouraged to promote sports activities and ventures [71]. Given the relationship between perceived quality, perceived value, and satisfaction with the future intentions of users of sports services, it is important for institutions and researchers to be aware of the impact that these have on educational sports services aimed at the school-age population, and so, on the development of active life habits and positive social values. The results of our study suggest that the evaluation of perceived quality, satisfaction, and perceived value in relation to extracurricular sports activities offered by schools is of importance. Student satisfaction was the value judgment that obtained the highest value.

A relationship has been found between the extent of communication by an organization and loyalty to the organization. In the same way, the perception of sports spaces is related to the ability to present complaints and claims against school sports organizations. Perceived value and satisfaction are precursors to loyalty and the adaptation to the price of sports organizations for school-age children. 
These results indicate that measures should be taken to promote loyalty and the continuity of sports practice in schools. In the same way, these results can help to establish strategies by which schools can increase the intentions of students in order to increase loyalty and adherence to sports as a tool for developing healthier habits and lifestyles [26].

\section{Limitations and Future Research}

The main contribution of this study is to shed light on the research gap in the area of extracurricular sports activities in educational institutions, as a transmitter of education that contributes to the improvement of social sustainability. Extracurricular sports in clubs and other such institutions were not included in this study given their limited educational role. One constraint of this study was the scarce bibliography that exists on the evaluation and relationship of quality, value, satisfaction, and future intentions with respect to the population that was the object of this study, and in particular, to extracurricular sports activities. A comparison with other works on mediating variables and other influencing factors on loyalty and intentions to carry out extracurricular sports practice would be important for new studies. New lines of research could analyze the assessments of parents and compare their satisfaction with the influence that they have on the permanence of schoolchildren in sports activities.

Author Contributions: Conceptualization, M.A.C.; data curation, R.P.-O.; investigation, R.P.-O.; methodology, A.N.; software, M.A.C.; supervision, R.P.-O., A.N.; validation, R.N., A.N.; writing—original draft, R.P.-O., M.A.C.; writing-review and editing, M.A.C., R.N.

Funding: This research received no external funding.

Conflicts of Interest: The authors declare no conflict of interest.

\section{References}

1. Lemke, W. El papel del deporte en la consecución de los Objetivos de Desarrollo Sostenible. Cron. ONU 2016, 53, 6-9. [CrossRef]

2. Murga-Menoyo, M.A. Competencias para el desarrollo sostenible: Las capacidades, actitudes y valores meta de la educación en el marco de la Agenda global post-2015. Foro Educ. 2015, 13, 55-83. [CrossRef]

3. Mitova, S.; Popova, D.; Gramatikova, M. Relevance of the issue for healthy lifestyle formation in adolescents. Act. Phys. Educ. Sport 2015, 5, 234-236.

4. Tammelin, R.; Yang, X.; Leskinen, E.; Kankaanpaa, A.; Hirvensalo, M.; Tammelin, T.; Raitakari, O.T. Tracking of physical activity from early childhood through youth into adulthood. Med. Sci. Sports Exerc. 2014, 46, 955-962.

5. Yan, A.; Voorhees, C.; Beck, K.; Wang, M. A social ecological assessment of physical activity among urban adolescents. Am. J. Health Behav. 2014, 38, 379-391. [CrossRef]

6. Beltrán, V.J.; Devís, J.; Peiró, C. Actividad física y sedentarismo en adolescentes de la Comunidad Valenciana. Revista Internacional de Medicina y Ciencias de la Actividad Física y el Deporte 2012, 45, 123-127.

7. Gil, J.; Moreno, E.; Vinaccia, S.; Contreras, F.; Fernández, H.; Londoño, X.; Medellín, J. Hábitos básicos de salud y creencias sobre salud y enfermedad en adolescentes de España, Colombia y México. Rev. Latinoam. Psicol. 2004, 36, 483-504.

8. Grao-Cruces, A.; Nuviala, A.; Fernández, A.; Porcel, A.M.; Moral, J.E.; Martínez, E.J. Adherencia a la dieta mediterránea en adolescentes rurales y urbanos del sur de España, satisfacción con la vida, antropometría y actividades físicas y sedentarias. Nutr. Hosp. 2013, 28, 1129-1135.

9. Organización para la Cooperación y el Desarrollo Económico. Panorama de la educación. Indicadores de la OCDE 2015. Informe español; Ministerio de Educación, Cultura y Deporte: Madrid, Spain, 2015.

10. Camacho, M.J.; García, E.F.; Rico, E.R.; Ángel, J. La Educación Física escolar en la promoción de la actividad física orientada a la salud en la adolescencia: Una revisión sistemática de programas de intervención. Rev. Complut. Educ. 2013, 24, 9-26. [CrossRef]

11. Carrasco, H.; Ríos, L.; Tamayo, I.; Cajas, B.; Garrido, R. Efectos de un programa extraescolar basado en juegos reducidos sobre la motivación y las necesidades psicológicas básicas en las clases de educación física. Revista Iberoamericana de Psicología del Ejercicio y el Deporte 2015, 10, 23-31. 
12. Grao-Cruces, A.; Ruiz, R.; Moral, J.E.; Ruiz, A.; Martinez, E. Effects of a steps/day programme with evaluation in physical education on body mass index in schoolchildren 11-12 years of age. Kinesiol. Int. J. Fundam. Appl. Kinesiol. 2016, 48, 132-141. [CrossRef]

13. Chillón, P.; Ortega, F.B.; Ruiz, J.R.; Evenson, K.R.; Labayen, I.; Martínez-Vizcaino, V.; Sjöström, M. Bicycling to school is associated with improvements in physical fitness over a 6-year follow-up period in Swedish children. Prev. Med. 2012, 55, 108-112. [CrossRef]

14. Villa, E.; Pérez, I.J.; Ruíz, J.R.; Delgado, M.; Chillón, P. El desplazamiento activo al colegio: Una propuesta de intervención escolar. Tándem Didáctica de la Educación Física 2014, 46, 24-32.

15. Troiano, R.P.; Berrigani, D.; Dodd, K.W.; Masse, L.C.; Tilert, T.; McDowell, M. Physical activity in the United States measured by accelerometer. Med. Sci. Sports Exerc. 2008, 40, 181-188. [CrossRef]

16. Baños, R.; Ruiz-Juan, F.; Baena-Extremera, A.; García-Montes, M.E.; Ortiz-Camacho, M.M. Leisure-time physical activity in relation to the stages of changes and achievement goals in adolescents: Comparative study of students in Spain, Costa Rica, and Mexico. Sustainability 2018, 10, 2581. [CrossRef]

17. Botines, M.P.; De Peray, J.L. Trabajando hacia una salud pública sostenible mediante la interrelación de lo ambiental y lo social. Informe SESPAS 2010. Gac. Sanit. 2010, 24, 74-77. [CrossRef]

18. Mena-Bejarano, B. Análisis de experiencias en la promoción de actividad física. Revista de Salud Pública 2006, 8, 42-56. [CrossRef]

19. Smith, L.; López, G.F.; Díaz, A.; Stubbs, B.; Dowling, M.; Scruton, A.; Pardhan, S. Barriers and facilitators of physical activity in children of a South Asian ethnicity. Sustainability 2018, 10, 761. [CrossRef]

20. Van, E.; Page, A.; Ommundsen, Y.; Griffin, S. Behavioural and social correlates of sedentary time in young people. Br. J. Sports Med. 2010, 44, 747-755.

21. Abarca, A.; Bois, J.E.; Zaragoza, J.; Generelo, E.; Julian, J.A. Ecological correlates of physical activity in youth: Importance of parents, friends, physical education teachers and geographical localization. Int. J. Sport Psychol. 2013, 44, 215-233.

22. Guthold, R.; Cowan, M.J.; Autenrieth, C.S.; Kann, L.; Riley, L.M. Physical activity and sedentary behavior among schoolchildren: A 34-country comparison. J. Pediatr. 2010, 157, 43-49. [CrossRef]

23. Štefan, L.; Mišigoj-Duraković, M.; Devrnja, A.; Podnar, H.; Petrić, V.; Sorić, M. Tracking of physical activity, sport participation, and sedentary behaviors over four years of high school. Sustainability 2018, 10, 3104. [CrossRef]

24. Beltrán, V.J.; Sierra, A.C.; Jiménez, A.; González-Cutre, D.; Martínez, C.; Cervelló, E. Diferencias según género en el tiempo empleado por adolescentes en actividad sedentaria y actividad física en diferentes segmentos horarios del día. Retos Nuevas Tendencias en Educación Física Deportes y Recreación 2017, 31, 3-7.

25. Sachs, J.; Schmidt-Traub, G.; Kroll, C.; Lafortune, G.; Fuller, G. SDG Index and Dashboards Report 2018; Bertelsmann Stiftung and Sustainable Development Solutions Network (SDSN): New York, NY, USA, 2018.

26. UNESCO. Más Allá de 2015. la Educación que Queremos. 2014. Available online: http://www.unesco.org/ new/fileadmin/MULTIMEDIA/HQ/ED/ED_new/pdf/BEYOND2015-TheEdWeWant_Final_Brochure-SPA.pdf (accessed on 27 November 2018).

27. UNESCO. Declaración de Aichi-Nagoya Sobre la Educación Para el Desarrollo Sostenible. In Proceedings of the Conferencia Mundial de la UNESCO sobre la Educación para el Desarrollo Sostenible, Aichi-Nagoya, Japan, 10-12 November 2014; Reuniones de las Partes Interesadas Okayama (Japón), 4-8 November. Available online: https://unesdoc.unesco.org/ark:/48223/pf0000231074_spa (accessed on 27 November 2018).

28. Labeaga, J.M.; Lado, N.; Martos, M. Behavioural loyalty towards store brands. J. Retail. Consum. Serv. 2007, 14, 347-356. [CrossRef]

29. Walsh, G.; Evanschitzky, H.; Wunderlich, M. Identification and analysis of moderator variables: Investigating the customer satisfaction-loyalty link. Eur. J. Mark. 2008, 42, 977-1004. [CrossRef]

30. Nuviala, A.; García, J.; Bernal, A.; Grao-Cruces, A.; Teva-Villén, R.; Pérez-Ordás, R. Adaptación y validación de la escala de intenciones futuras de comportamiento en usuarios de servicios deportivos. Univ. Psychol. 2014, 13, 1017-1082. [CrossRef]

31. Yacout, O. Service quality, relational benefits, and customer loyalty in a non-western context. SAM Adv. Manag. J. 2010, 75, 4-18.

32. Howat, G.; Crilley, G.; McGrath, R. A focused service quality, benefits, overall satisfaction and loyalty model for public aquatic centres. Manag. Leis. 2008, 13, 139-161. [CrossRef] 
33. Grayson, K.; Ambler, T. The dark side of long-term relationships in marketing services. J. Mark. Res. 1999, 36, 132-141. [CrossRef]

34. Cordera, R. Globalización en crisis; por un desarrollo sostenible. Econ. UNAM 2017, 14, 3-12. [CrossRef]

35. Vidarte, J.A.; Vélez, C.; Sandoval, C.; Alfonso, M.L. Actividad física: Estrategia de promoción de la salud. Hacia la Promoción de la Salud 2011, 16, 202-218.

36. García-Molina, V.A.; Carbonell-Baeza, A.; Delgado, M. Beneficios de la actividad física en personas mayores. Revista Internacional de Medicina y Ciencias de la Actividad Física y el Deporte 2010, 10, 556-576.

37. Poblete-Valderrama, F.; Castillo, C.M.; Sandoval, E.D.; Silva, P.V.; García, M.A. Depresión, cognición y calidad de vida en adultos mayores activos. Revista Ciencias de la Actividad Física UCM 2015, 16, 71-77.

38. González, A.J.G.; Froment, F. Beneficios de la actividad física sobre la autoestima y la calidad de vida de personas mayores. Retos Nuevas Tendencias en Educación Física Deportes y Recreación 2018, 33, 3-9.

39. Herrera, E.; Pablos, A.; Chiva-Bartoll, O.; Pablos, C. Effects of physical activity on perceived health and physical condition on older adults. J. Sport Health Res. 2017, 9, 27-39.

40. Roca, R.E. Actividad física y salud en el adulto mayor de seis países latinoamericanos: Review. Revista Ciencias de la Actividad Física UCM 2016, 17, 77-86.

41. Fernández-Rio, J.; Cecchini, J.A.; Mendez-Giménez, A.; Méndez-Alonso, D. Meta-percepciones y auto-percepciones de competencia en adolescentes, motivación, intención de práctica de actividad física y actividad física. Revista de Psicología del Deporte 2018, 18, 75-79.

42. Grao-Cruces, A.; Fernández-Martínez, A.; Teva-Villén, M.R.; Nuviala, A. Physical self-concept and intention to be physically active in participants of the sport schools program. J. Sport Health Res. 2017, 9, 15-25.

43. Muros, J.J.; Castillo, A.S.; García, H.L.; Díaz, M.Z. Asociaciones entre el IMC, la realización de actividad física y la calidad de vida en adolescentes. Cultura Ciencia y Deporte 2009, 4, 159-165.

44. Howat, G.; Assaker, G. The hierarchical effects of perceived quality on perceived value, satisfaction, and loyalty: Empirical results from public, outdoor aquatic centres in Australia. Sport Manag. Rev. 2013, 16, 268-284. [CrossRef]

45. Kim, M.; Trail, G. The effects of service provider employment status and service quality exchange on perceived organizational image and purchase intention. Sport Manag. Rev. 2010, 13, 225-234. [CrossRef]

46. Kyle, G.; Theodorakis, N.D.; Karageorgiou, A.; Lafazani, M. The effect of service quality on customer loyalty within the context of ski resorts. J. Park Recreat. Adm. 2010, 28, 1-15.

47. Theodorakis, N.; Howat, G.; Ko, Y.J.; Avourdiadou, S. A comparison of service evaluation models in the context of sport and fitness centres in Greece. Manag. Leis. 2014, 19, 18-35. [CrossRef]

48. Nuviala, A.; Tamayo, J.; Nuviala, R.; Pereira, E.; Carvalho, J. Predicción del abandono deportivo en la adolescencia a través del estudio de la calidad percibida. Movimento 2012, 18, 221-239. [CrossRef]

49. Nuviala, A.; Grao-Cruces, A.; Tamayo, J.; Nuviala, R.; Álvarez, J.; Fernández-Martínez, A. Diseño y análisis del cuestionario de valoración de servicios deportivos (EPOD2). Revista Internacional de Medicina y Ciencias de la Actividad Física y el Deporte 2013, 13, 419-436.

50. Haro-González, M.; Pérez-Ordás, R.; Grao-Cruces, A.; Nuviala, R.; Nuviala, A. Female users of unisex fitness centres and of fitness centres exclusive for women: Satisfaction. Int. J. Sports Mark. Spons. 2018, 19, 384-395.

51. Declaración de Helsinki de la Asociación Médica Mundial. Principios Éticos Para Las Investigaciones Médicas en Seres Humanos. In Proceedings of the $64^{\mathrm{a}}$ Asamblea General, Fortaleza, Brasil, October 2013. Available online: https://www.wma.net/es/policies-post/declaracion-de-helsinki-de-la-amm-principioseticos-para-las-investigaciones-medicas-en-seres-humanos/ (accessed on 27 November 2018).

52. Bernal, A. Fidelización de Clientes en Organizaciones Deportivas: Calidad, Valor Percibido y Satisfacción Como Factores Determinantes. Ph.D. Thesis, Universidad de Sevilla, Sevilla, Spain, 2014.

53. Nuviala, A.; Pérez-Ordás, R.; Boceta, M.; Grao-Cruces, A.; Nuviala, R.; González, J.A. Calidad, satisfacción y valor percibido de los usuarios de un servicio deportivo público. Movimento 2012, 18, 11-32. [CrossRef]

54. Rial, J.; Mallou, J.; Boubeta, A.; Deus, J. Modernización y medida de la Calidad Percibida en centros deportivos: La escala QSport-10. RICYDE Revista Internacional de Ciencias del Deporte 2010, 6, 57-73. [CrossRef]

55. Afthinos, Y.; Theodorakis, N.D.; Nassis, P. Customers' expectations of service in Greek fitness centers: Gender, age, type of sport center, and motivation differences. Manag. Serv. Qual. Int. J. 2005, 15, 245-258. [CrossRef]

56. Nuviala, A.; Tamayo, J.; Nuviala, R. Calidad percibida del deporte escolar como predictor del abandono deportivo en adolescentes. Revista Internacional de Medicina y Ciencias de la Actividad Física y del Deporte 2012, 12, 389-404. 
57. Castillo, E.; Tornero, I.; García, J.A. Relación entre actividad física, alimentación y familia en edad escolar. Retos Nuevas Tendencias en Educación Física Deportes y Recreación 2018, 34, 85-88.

58. Nuviala, A.; Salinero, J.J.; García, M.; Gallardo, L.; Burillo, P. Satisfacción con los técnicos deportivos en la edad escolar. Revista de Psicodidáctica 2010, 15, 121-135.

59. Lucio, M. Calidad y Seguridad de Las Instalaciones y el Material Deportivo, en Los Centros de Educación Secundaria y Bachillerato de la Provincia de Málaga. Ph.D. Thesis, Universidad de Málaga, Málaga, Spain, 2003.

60. Montalvo, J.; Felipe, J.L.; Gallardo, L.; Burillo, P.; García, M. Las instalaciones deportivas escolares a examen: Una evaluación de los institutos de educación secundaria de Ciudad Real. Retos Nuevas Tendencias en Educación Física Deportes y Recreación 2010, 17, 54-58.

61. Nuviala, A.; Grao-Cruces, A.; Teva, R.; Pérez-Turpin, J.A.; Pérez-Ordás, R.; Tamayo, J. Duration of membership at sports centers and reasons for quitting. Percept. Mot. Skills 2013, 117, 733-741. [CrossRef]

62. Varela, J.; Rial, A.; García, E. Presentación de una escala de satisfacción con los servicios sanitarios de atención primaria. Psicothema 2003, 15, 656-661.

63. Olsen, L.; Johnson, M. Service equity, satisfaction, and loyalty: From transaction-specific to cumulative evaluations. J. Serv. Res. 2003, 5, 184-195. [CrossRef]

64. Llorens, J. La lealtad de Los Aficionados al Fútbol. Una Explicación en Base al Valor de Marca de Su Equipo y Su Nivel de Implicación. Ph.D. Thesis, Universitat Jaume I, Castellón de la Plana, Spain, 2011.

65. Calabuig, F.; Crespo, J.; Mundina, J. Efecto del coste percibido, la calidad de servicio y la satisfacción sobre las intenciones futuras del espectador. Estudios de Economía Aplicada 2012, 30, 619-632.

66. Oh, S.H.; Lee, H.S.; Kim, S.J. The effects of service quality and relationship benefits on relationship commitment and customer loyalty in membership fitness club. J. Glob. Sch. Mark. Sci. 2011, 21, 115-125. [CrossRef]

67. Trail, G.; Anderson, D.; Fink, J. Consumer satisfaction and identity theory: A model of sport spectator conative loyalty. Sport Mark. Q. 2005, 14, 98-111.

68. Valle, P.; Silva, J.; Mendes, J.; Guerreiro, M. Tourist satisfaction and destination loyalty intention: A structural and categorical analysis. Int. J. Bus. Sci. Appl. Manag. 2006, 1, 25-44.

69. Ferrand, A.; Robinson, L.; Valette-Florence, P. The intention-to-repurchase paradox: A case of the health and fitness industry. J. Sport Manag. 2010, 24, 83-105. [CrossRef]

70. McDougall, G.; Levesque, T. Customer satisfaction with services: Putting perceived value into the equation. J. Serv. Mark. 2000, 14, 392-410. [CrossRef]

71. Pacto Global Red Chile. Hacer de Los Objetivos Globales, Negocios Locales. 2018. Available online: https://pactoglobal.cl/objetivos-de-desarrollo-sostenible-ods/ (accessed on 19 June 2019). 